\title{
GERM-LINE ENGINEERING: A FEW EUROPEAN VOICES
}

\begin{abstract}
We have surveyed various recent European opinions on germ-line engineering. The majority express more or less severe reservations about any interventions on the human germ-line, including therapeutic ones. However, they are divided over the pragmatic, or categorical-ethical nature of the relevant arguments. This split reflects two competing views of technology. The 'pessimistic' one is deeply concerned by the slippery slope leading from bona fide therapeutic applications of genetic engineering to eugenic practices. It insists that, if anything can defend us against these evils, it must be a set of strong, ethically-based prohibitions. The other, 'optimist' view is more confident in the discriminating powers of societal regulation. We argue for the latter view and suggest that the pragmatic arguments brought to this debate are less problematic than the ethical ones.
\end{abstract}

Key Words: embryo selection, eugenics, germ-line engineering, human gene therapy, slippery slope

\section{INTRODUCTION}

In the last few years, the problems of genetic engineering and its introduction into human medicine have been debated as hotly in Europe as in North America. As regards these issues - as well as bioethical problems generally - it is easy to identify in Europe two contrasting attitudes. One could be termed 'pessimistic'. Its hallmarks are a very skeptical attitude towards the potential benefits of the new technologies, a great sensitivity to their potential evils and, even more characteristically, a tendency to interpret these evils quite broadly. Proponents of this view generally advocate sweeping prohibitions or severe regulation of various genetic technologies, while at the same time expressing doubts

Alex Mauron, Ph.D., Scientific Collaborator, Louis Jeantet Foundation for Medicine, and Department of Biochemistry, University of Geneva, P.O. Box 277, CH-1211, Geneva 17, Switzerland.

Jean-Marie Thévoz, D.D., Research Associate, Louis Jeantet Foundation for Medicine, and Faculty of Theology, University of Geneva, P.O. Box 277, CH-1211, Geneva 17, Switzerland.

The Journal of Medicine and Philosophy 16: 649-666, 1991.

(C) 1991 Kluwer Academic Publishers. Printed in the Netherlands. 
that sufficiently defensive regulation can really be achieved. Theirs is a view of technology where intended good and unintended evil, innocent experimentation and large-scale catastrophic consequences are connected by a tight network of 'slippery slopes'. Although by no means absent elsewhere, this attitude seems particularly prevalent in the bioethical literature from German-speaking countries, where it has crystallized into a kind of conventional wisdom. The other world-view is an 'optimism' that is much harder to delineate with any precision: suffice it to say that Anglo-Saxon and Latin lands, however much they differ in their legal traditions, seem as a rule more confident in their ethico-legal capability to promote good and prevent evil without, as it were, throwing the baby with the bathwater.

In Switzerland, with its unique cohabitation of German and Romance cultures, these two world views must come to terms with each other. We have observed (Bourrit et al., 1989) how they interacted when the Federal Expert Commission for Human Genetics and Reproductive Medicine published the Amstad Report (1988), a document containing a wide range of proposals for the regulation of various procedures both in human genetics (diagnostics, genetic therapy) and human reproduction (IVF, surrogate motherhood). In this paper we will follow out the implications of these two world views of germ-line engineering by discussing critically a (admittedly subjective) selection of European opinions on this topic. ${ }^{1}$ In Table I, we have categorized several European voices (with a few others included for comparison) according to their conclusion on two issues: somatic versus germ-line intervention, gene therapy versus enhancement genetic engineering. Horizontally, we distinguish: (i) refusal of any form of human gene therapy; (ii) acceptance of somatic gene therapy only (the target of the genetic modification must be restricted to the DNA of somatic cells); (iii) some degree of acceptance of germ-line therapy (GLT; this includes all DNA modifications that would be transmissible to future persons, namely interventions on the DNA of gametes and their precursors and also on the cells of early embryos where the germ line has not yet segregated). Vertically, opinions are categorized according to their acceptance of a therapeutic goal only, (curing a medically defined disease entity in an individual and possibly his or her descendants), or acceptance of an enhancement goal as well (modifying the genome of individuals with a view to providing them with capabilities or biological properties 
TABLE I

Genetic engineering on humans: Selection of opinions

\begin{tabular}{|c|c|c|c|}
\hline & Therapeutic goal & & $\begin{array}{l}\text { Ameliorative } \\
\text { (enhancement) }\end{array}$ \\
\hline & Guidelines & Analyses & Analyses \\
\hline $\begin{array}{l}\text { Misgivings against } \\
\text { all gene therapy }\end{array}$ & & $\begin{array}{l}\text { Jonas } 1985 \\
\text { Ruh } 1989\end{array}$ & \\
\hline $\begin{array}{l}\text { Approving somatic } \\
\text { gene therapy only }\end{array}$ & $\begin{array}{l}\text { Benda Report } 1986 \\
\text { NHMRC } 1987 \\
\text { EMRC } 1988 \\
\text { Amstad Report } 1988 \\
\text { Council of Europe } 1989 \\
\text { Fifth Inter. Summit } 1988 \\
\text { Points to Consider } 1989 \\
\text { Livre Blanc } 1990\end{array}$ & $\begin{array}{l}\text { Weatherall } 1988 \\
\text { Pembrey } 1988 \\
\text { Vogel } 1989\end{array}$ & \\
\hline $\begin{array}{l}\text { Not disapproving } \\
\text { germ-line therapy }\end{array}$ & Council of Europe 1982 & $\begin{array}{l}\text { OTA } 1984 \\
\text { Walters } 1986 \\
\text { Bayertz } 1987 \\
\text { Anon. (Nature) } 1988 \\
\text { Anderson } 1989 \\
\text { Fowler } 1989\end{array}$ & $\begin{array}{l}\text { Glover } 1984 \\
\text { Engelhardt } 1986\end{array}$ \\
\hline
\end{tabular}

that go beyond the mere restoration of normal functions). A further distinction was made according to 'literary genre', viz. normative statements of official bodies on one hand, individual opinions and scholarly efforts on the other. Perusal of this table reveals immediately the following points:

(a) There is a large consensus against the use of germ-line engineering to 'improve' human beings either individually or collectively. The minority view expressed by Glover (1984) seems motivated mainly by a skepticism about the very concept of 'therapeutic' and more specifically, its delimitation from 'enhancement'. In this respect however, it is interesting to observe that the European near-consensus agrees with the thinking of a major American pioneer of gene therapy, W. French Anderson. Over the years (Anderson, 1980, 1985, 1989, 1990), he moved to a position where he asserts forcefully that GLT can be conceptually and practically distinguished from enhancement germ-line engineering and that the latter is indeed illegitimate.

(b) Statements with an obvious normative intent (such as those 
coming from official bodies) tend to exclude GLT as well as enhancement engineering. They leave only somatic gene therapy as an open option, recognizing its conceptual closeness to other acceptable therapies such as grafts.

(c) Authors expressing personal views on the problem range all the way from those who have serious misgivings about any use of gene technology in the human sphere to a more or less guarded acceptance for GLT.

Although enhancement germ-line engineering seems 'out' for the vast majority of European discussants, there is clearly more uncertainty about using recombinant DNA techniques on the germ line for bona fide therapeutic purposes. On one hand, the therapeutic goal seems strong enough to legitimize GLT in specific cases such as Huntington's disease, on the other its openended character, its 'irreversibility' (an often used, but ambiguous term), call for a reserved attitude or even an complete prohibition. This hesitation can be traced through the pronouncements of the Council of Europe, which is the only major political institution that connects together all democratic countries in Europe and is growing into an important ethico-legal authority. Its Recommendation 934 (Council of Europe, 1982) suggested that their should be a new article in the European Convention on Human Rights guaranteeing "the right to inherit a genetic pattern which has not been artificially changed" (R934,4i), but foresees exceptions "in accordance with certain principles which are recognised as being fully compatible with respect for human rights (as, for example, in the field of therapeutic applications)". We are not told what these principles are but they would seem to allow GLT. Later on however, the Council of Europe came back on the therapeutic exception in Recommendation 1100 and declared expressly: "Any form of therapy on the human germinal line shall be forbidden" (Council of Europe, 1989, appendix pt.18). Therefore we will restrict our more detailed examination on arguments pertaining to GLT, since this is clearly the most contentious issue.

\section{THE ARGUMENTS AGAINST GERM-LINE THERAPY ARE OF TWO KINDS}

Arguments presented in opposition to GLT can be categorized in two classes: those which are largely pragmatic, including arguments pointing to an unfavorable balance of benefits versus risks, 
or more importantly, to the existence of alternative, more palatable techniques that could achieve the same legitimate ends; and those that can be termed ethical in a broad sense, including appeals to basic human rights. By far the strongest pragmatic argument against GLT is that selection of healthy embryos will always be preferable to gene therapy of defective ones. ${ }^{2}$ The possibility of correcting a deleterious mutation in embryos obtained by in-vitro fertilization presupposes an ability to distinguish affected and healthy embryos from one another. As a matter of fact, the latter ability is very much closer at hand than the former (see Handyside, 1990). Since however, in any realistic situation, there will always be some healthy embryos alongside the defectives ones, there is literally nothing else left to do than to transfer the healthy embryos in the prospective mother's womb. The question of embryo therapy cannot arise. This has been pointed out repeatedly by many participants in the GLT debate (Pembrey, 1988; Weatherall, 1988; Vogel, 1989, pp.125-126; Kaplan-Delpech, 1989, Chap.19). ${ }^{3}$

The strength of this argument seems to have been missed by some ethicists. For instance, protestant theologian Hans Ruh (1989) states that when dealing with GLT, prohibitions based on pragmatic arguments will simply not do, because they have a way of getting watered-down and eventually abandoned when the progress of science goes past them. This may conceivably hold for prohibitions that are linked explicitly to the current state of scientific knowledge (e.g., Mouvement Universel pour la Responsabilité Scientifique (1989): "Given the current state of our knowledge, the genetic endowment of man should not be modified in a heritable manner", or risk-benefit considerations) but misses the point of the above argument entirely. The imperative it refers to, namely transferring healthy embryos and not touching the others, is built into the very situation at hand. It cannot be abolished by some unexpected biological discovery in the way a running calculation of risk vs. benefit can suddenly be upset by new scientific or technical knowledge. However, we should point out that the core of Ruh's argument seems to be that any pragmatic argument, by way of its very nature, falls short of what is needed to defend mankind of what he feels to be the unavoidably eugenic consequences of germ-line engineering. We will come back to this issue later on. 
Arguing against germ-line engineering and GLT from a basic human right to one's unmodified genetic endowment is a commonly adopted position in various European sources, such as legal pronouncements (Council of Europe, 1982, 1989), government-appointed committees (Benda, 1986; Amstad, 1989), programmatic statements of non-official bodies (Mouvement Universel pour la Responsabilité Scientifique, 1989) or scholarly papers (Agius, 1989). It is probably not easy for a non-speaker of French or German to feel how instinctively seductive an appeal to the 'common genetic patrimony of mankind' can be. This is because no English word conveys the same complexity of meaning as the French patrimoine (or the German: Erbgut). Initially it means the assets belonging to an individual, but with special reference to the law of inheritance. In other words, patrimoine is the sum-total of somebody's possessions, which he will bequeath to his or her heirs. By a switch from the individual sphere to the collective, the word has acquired a figurative sense which applies especially to cultural matters. When hearing the expression: le patrimoine culturel de l'humanité, one thinks immediately of cathedrals and Greek temples, of the Iliad and Hamlet, of UNESCO and the campaign to save Venice. Thus the same concept points to individual possessions, subjected to unlimited property-rights, ius uti et abuti, and to the collective assets of a community (or of mankind), all that is both irreplaceable and of enduring worth, and therefore subject to specific forms of social protection. So far, the English word 'heritage' is very similar. On the other hand, however, the same word is used as in patrimoine génétique to mean something like an individual's genetic endowment. In fact, it is used basically as a synonym of 'genetic material' or 'genome'. This is especially so in popular writings about biology where it is probably felt to be easier to understand then the correct specialized terms. Now it turns out that the same switch from the individual to the collective has probably occurred in this latter context. From the notion of an individual genetic endowment, which an autonomous subject might just possibly be allowed to manipulate, one has moved to the idea of a collective genetic heritage, whose unique worth is above any individual interest. Just as an individual cannot tear down a Gothic chapel for his private convenience, one cannot touch the 'genetic patrimony', even if some persons would benefit. 
We think that it is mainly for these purely semantic reasons that the idea of an untouchable genetic endowment of mankind has acquired the status of an obvious truth. Its superficial plausibility has prevented its proponents from really arguing for it. One conceivable foundation for it could be found in the ethic of Hans Jonas, a thinker whom we will discuss again later because of his major influence on bioethics in continental Europe. For Jonas, mankind has an ontological responsibility toward the preservation of 'the image of man' and this responsibility is particularly relevant to biomedical technology. If we were to accept that such an imperative exists and if we assumed in addition that the human genome - or rather such aspects of it as would be changed by GLT - is central to the image of man, then (but only then) it would follow that touching the human genome should be illegitimate in itself.

Another context in which the 'common patrimony' theme appears is in discussions about natural resources that should not be privately or nationally appropriated, such as minerals on the sea-bed (this is explicitly referred to by Agius), or 'germ-plasm', i.e., the genetic resources represented by the large, but endangered, diversity of plant species and varieties, especially in Third World countries. There lie the roots of yet another confusion: it is tempting to reason that, since germ-plasm is a common resource subject to specific forms of social control, the same should apply to the 'genetic patrimony of mankind'. But it is not at all clear in what sense the human genome can be considered a 'resource'. In fact, the utilitarian overtones of such an idea would seem rather unfortunate, especially to those advocating the 'image-of-man' style of bioethics.

\section{ARE PRAGMATIC ARGUMENTS INHERENTLY FLAWED?}

We have mentioned that Ruh, along with other philosophers and theologians, is querying the pragmatic arguments as such. He asks: "Is GLT to be rejected on categorical-ethical grounds or from the point of view of our present knowledge"? Ruh thinks that we must forswear GLT once and for all on a 'categorical-ethical' basis. Otherwise the following slippery-slope scenario would develop: Initially, there is a consensus that GLT is technically not feasible and ethically uninteresting. Meanwhile however, scientists pursue their basic research and explore somatic gene therapy. At one 
point, GLT becomes possible as well and a few people start to practice it. It eventually becomes acceptable therapy and from then on, one moves to the correction of minor defects and finally to ameliorative genetic engineering and eugenics.

The 'gravity force' supposedly driving us down this slippery slope is the therapeutic imperative, namely the possibility - and therefore the obligation (principle of beneficence) - of alleviating an individual's suffering. Ruh proposes to replace this individualistic and short-term criterion by what he calls specieshistorical norms: They mandate that we ought to transmit to future generations, (i) the capability to survive; (ii) the capability to live a genuinely human life (with its ups and downs); (iii) the freedom to choose and direct one's own destiny. 'Tampering' with the genome would endanger these values and therefore Ruh claims that to safeguard them, we need to move beyond prudential considerations to a forceful, final, ethically-based prohibition of all germ-line engineering including GLT and even to a' 'structural inability' to do research related to it.

Ruh appeals to three kinds of arguments, viz. the fragility of pragmatic considerations, our responsibilities towards future generations and the slippery slope driven by what we could call the therapeutic 'excuse' for questionable feats of genetic engineering. All three arguments are problematic. We have already discussed the pragmatic preference of embryo selection over GLT. Furthermore, it is hard to see why ethical arguments should have inherently more force than prudential ones. Moral commands derive their strength not from the solemnity with which they were proclaimed once and for all, but from the renewed assent and conviction of each generation of humans. As to the three values (survival, humanity, freedom) that, for Ruh, encompass our duties to future generations, they are not controversial. We certainly have a duty to mind the consequences of our actions for the future (non-maleficence). Yet the implications in the case at hand are far from clear. Again one must stress, that it is not enhancement engineering that is considered here but germ-line interventions with a bona fide therapeutic purpose. After all, GLT merely aims at restoring an order of things that obtained previously, but was disturbed by genetic mutation. Unlike enhancement engineering, it stays within the bounds of the traditional, restorative ethos of medicine. Therefore, it is hard to see in what way GLT specifically endangers the three long-term values quoted above. It would do 
so no more (and no less) than many developments in medicine and therefore Ruh's argument lacks focus.

Ruh is quite right in pointing to our duties to future generations as relevant to the problem of GLT. However, without further clarification, such duties could be deeply ambiguous. In fact, had they known about genetic engineering, some of the 'progressive' eugenists of the nineteen-thirties (e.g., Hermann J. Muller or Julian Huxley), would probably have claimed that we owe it to future generations to fix their genes! We all agree that we have a responsibility towards the future but are divided over the means of fulfilling it. One of the dividing factors is the world-view implied by the slippery-slope argument. By conjuring up a technological scenery made of a maze of slippery slopes, inextricably weaving together the Good, the Bad and the Horrible, proponents of this view have painted themselves into a corner: While wanting us to resist the encroachments of genetic engineering, they have undermined the very basis for such a resistance, viz. the ability to set limits. We must avoid the slippery slope, but whatever we do, we are already on it....

As B. Williams noted (1986), the slippery-slope argument is not always a bad one but in those cases where it is logically sound, it must refer back to supportive empirical data. But this is precisely the kind of information that users of the argument usually feel excused from providing. For instance, Ruh sets great store by the slippery-slope argument as applied to the transition from somatic to germ-line therapy, and from GLT to enhancement engineering and eugenics. The idea that developing somatic gene therapy eventually will make GLT irresistible comes from the early literature on the subject (Walters, 1986). The argument runs as follows: once we have corrected the 'bad' gene into the 'good' one in a given tissue, why not fix the problem once and for all by making a similar correction in the germ-line? But this is not the direction in which the field has actually moved. From this initial understanding of the procedure, which we have called "orthogenic" (Mauron, 1990, unpublished conference), one has moved to the grafting analogy, the exogenous DNA being construed as a kind of 'naked' graft. Thereafter, interest has moved (partly at least) from the transformation of long-lived stem cells to more ephemeral, yet more accessible, cell types such as lymphocytes and endothelial cells. Another promising paradigm for the future seems to be the organoid system, a kind of composite 
graft including both artificial polymers and living, genetically engineered cells that provide the body with a missing substance, somewhat like an implantable pump (Culliton, 1990). If this promise materializes, somatic gene therapy would have moved from an orthogenic to a chemotherapeutic metaphor, its aim from correcting a genetic defect to compensating for it. Furthermore, the indication for such a therapy need no longer be a genetic disease strictly speaking: AIDS, cancer, emphysema are all now being considered candidates for this 'genetic' therapy. A similar shift of emphasis would attend to procedures eventually derived from other recent experimental findings, for instance that direct injection of DNA into muscles of mice leads to the synthesis of the appropriate protein for several months (Wolff, 1990). This form of treatment would no longer be recognizably genetic, except in the trivial sense that DNA plays a role in it. As a consequence, the slippery slope towards GLT is simply not there.

The slippery slope from GLT to eugenics is much harder to evaluate. For one thing, the recent evolution of the GLT concept has, if anything, increased our doubts that such a therapy can ever become a conceptually sound proposition. Now as regards eugenics, the word is all too often used rhetorically to cast a pall of obloquy over any aspect of human genetics that the writer happens to dislike. Nevertheless, we agree that the issue of eugenics must be raised in this context. We mentioned embryo selection as the realistic alternative to GLT. The possible eugenic implications of this procedure certainly exist (selection of sex and other 'desirable' characteristics, as opposed to prevention of major genetic pathology), but they are not really different than those of prenatal diagnosis in general. Likewise, the potential of embryo selection for ameliorative engineering is limited: all embryos subjected to the selection would be possible 'natural' offspring of their parents. Defending society from eugenic abuses of both embryo selection and prenatal diagnosis implies similar procedural steps in both cases, for instance reinforcing the patientcentered ethos of clinical genetics.

If one looks at the history of bioethical issues, the slippery slope really looks more like a ramshackle staircase: once in a while, we trip down a few steps. This makes us wake up, take stock of ethical shortcomings and climb up the stairs by appropriate measures such as societal regulation. An example of this process would be the setting up of Institutional Review Boards to oversee 
medical research with human subjects after the aberrant research practices at Tuskegee and Willowbrook had been exposed. In fact, it is not even always necessary to fall down the stairs before climbing up again, as the history of recombinant DNA regulation proves.

\section{THE JONASSIAN POSITION}

We chose to focus on the 'pessimistic' view of human genetics as expressed by Ruh, but could have discussed other writers from a significant group who show the pervasive influence of philosopher Hans Jonas. His thought is relevant not just to bioethics but to many discussions about the ills of our technological society. For Jonas and his followers, modern science and technology have created a completely new ethical situation, in which the reflective tools provided by the various ethical traditions are found wanting (Jonas, 1979, 1985). For one thing, modern technoscience has now become so powerful that it has given mankind a truly global leverage on this planet and its future. The reach of technoscience is now universal: the consequences of technoscientific choices stretch far and forcefully into space and time and mankind's responsibility has increased accordingly. Furthermore, Jonas thinks that good and bad effects of technoscience are increasingly linked together. In addition, Jonas is a firm believer in the technological imperative: there is no distance left between the mere possession of a new capability and its actual use. Novel technologies have a way of moving automatically from laboratory experiment to all-out, large scale implementation. Unwittingly, we let them reach the 'critical mass' where they escape our control. All this means that the 'old' ways of evaluating technoscience (e.g., cost-benefit analysis, sorting out good from bad consequences) are no longer up to the task. In their stead, a new ethical principle is necessary, viz. 'the predominance of negative prediction'. Faced with a technoscientific novelty, we must exercise our imagination to determine all thinkable effects, good or evil, and if there are any in the latter category, then we must utterly renounce this technology. A catastrophic consequence, if it is merely thinkable, and no matter how minuscule its probability, must be absolutely overriding.

Jonas is right in calling attention to prospective thinking as a duty of scientists and technologists. But the overridingness of bad 
consequences is utterly unworkable as an actual guide for action, as pointed out by critics such as Böckle (1988) and Sass (1987, 1988). The underlying assumption is that, in the face of technoscientific novelty, innocence lies in abstention. This is certainly wrong as an a priori principle: a moratorium or a final stop to a given line of research is not per se moral. For instance, let us imagine that the Asilomar conference, rather than replacing the Berg Moratorium by a procedural framework (Watson and Tooze, 1981), had decreed an irrevocable ban on all recombinant DNA research. We wager that our knowledge about the HIV virus would be far less advanced than it is. It is even doubtful that the agent of AIDS should have been identified and usable diagnostic procedures established: however much we suffer from our present impotence before AIDS, it would have been far worse still and we would have been prevented from even taking stock of the epidemic. Would we say then that the generation of 1975 had discharged its responsibility towards the generation of 1990 ?

\section{GERM-LINE THERAPY AND AUTONOMY}

In the European bioethical debate, one can often observe a certain distrust of autonomy-based arguments, based on an impression that they lead to a very 'laissez-faire' position such as that exemplified by Engelhardt (1986, 1987). That this is not necessarily so was extensively shown by Bayertz (1987). If we refuse heteronomous rules for ourselves and claim the right to draw our life-plan autonomously, we can hardly fail to grant the same breathing-space to others, including future others. In a way, this is not unlike Ruh's species-historical norms, that could be understood as the respect for the autonomous life-plans of future generations. In his book GenEthik (Chap.14), Bayertz shows clearly that this reciprocal character of autonomy ${ }^{4}$ precludes enhancement germ-line engineering, since it should make us refuse genetic modifications that impose on future human beings a specific view of the good life. Does this argument preclude GLT as well? Bayertz, an articulate critic of the jonassian tradition, thinks that it does not. For instance, it is hard to see why parents could not make legitimate proxy decisions about therapy on behalf of their embryos just as they do for a newborn child. But when the beneficiaries of GLT are more remote - as is the case when GLT is presented as the definitive 'genetic fix' as opposed to the 
restricted scope of somatic therapy or embryo selection - then the issue of autonomy warrants a second look.

We should assess GLT as a particular instance of intergenerational relationship and responsibility, as Ruh suggests. To be sure, the very idea of having duties to future generations as far as genetics is concerned can be double-edged, as we have discussed before. However, we are now in a position to reformulate the intergenerational questions as follows: do we want (or ought) to become doctors to future, not-yet-conceived persons, who would, generation after generation, be the indirect recipients of our benevolent genetic ministrations? It could be argued that we are, and have been for some time, doctors of the future. As has been pointed out often, many health-related practices (whether or not they come within the purview of medicine proper) change the genetic fitness of specific genotypes and therefore influence their frequency in the population (see, e.g., Vogel and Motulsky, 1986, pp. 448-449). That such changes are ultimately unpredictable should be obvious. After all, many of our actions lie at the start of causal chains whose ends are 'out of sight' and therefore can be considered unpredictable and also irreversible in some sense. Towards our own nature as towards nature at large, we simply cannot act on the principle: "Please leave this place the same as you found it". This is the reason why the mere appeal to intergenerational liability, without further qualification, is a feeble argument against GLT. Now the fact that some degree of genetic 'tinkering' is unavoidably blended into many actions that are ethically unobjectionable does not automatically legitimize a willful, targeted modification of future genomes (Jonas, 1985, pp. 282-283). We would still have to decide whether we would want to place future people's genes explicitly within the reach of our current medical powers. This is where we are inclined to say no: Germ-line therapy means in effect curing 'tomorrow's' people with 'today's' techniques and, more importantly, 'today's' conceptual tools (the quotes indicate that we are referring, as always in this paper, to some presumed future time in which germ-line therapy would be a workable proposition). But our ideas about genetic medicine will probably be looked upon as rudimentary and simplistic by future geneticists. Just as ameliorative germ-line engineering absolutizes particular, historically contingent preferences (Bayertz, 1989, Chap.13), we suggest that GLT may well give an excessive lasting power to a contingent state of 
medical science. In this respect, the eugenic policies of yesteryear and especially the more or less 'well-meaning' ones that were implemented in many democratic countries in the twenties and thirties should give us ample cause for embarrassment. They should make us skeptical that any of our projects for benefitting the future genetic constitution of mankind can hold water in the very long term.

\section{CONCLUSIONS}

Whether GLT will ever make sense in the future is far from obvious. Should this eventually be the case, we think that the onus would be on proponents of GLT to show that it is pragmatically preferable to diagnostic techniques such as, for instance, embryo selection. Furthermore, when evaluating technologies such as germ-line therapy that reach far into the future, we have to ask whether we could be placing a significant burden onto future generations by forcing them to take care of problems linked to our way of looking at a specific issue, especially if it includes a great deal of speculation. This emphasizes the essential role of the client-centered ethos typical of current medical genetics and discussed in relation with GLT by Fowler et al. (1989). According to this view, the proper concern of clinical genetics is to heal patients and, after a fashion, their immediate offspring. It does not and should not encompass future generations generally and even less 'cure the gene pool'. This deontological attitude provides a useful model for how medicine can keep its sphere of action technically and morally manageable. For ultimately, it would not be sustainable for medicine itself to have the sphere of its responsibility expand indefinitely in space and time.

In the European bioethical debate, proponents of the 'pessimistic' point of view, exemplified by Jonas, play a useful role in calling our attention to three important points. Firstly, there is the duty of scientists to use prospective thinking. Secondly, they never tire to remind us that a medical procedure is not necessarily ethical just because it has a therapeutic purpose. Finally, they point to intergenerational responsibility as an important component of several bioethical problems, although, as we have seen, a great deal of conceptual clarification remains to be done in this respect. The reason why this 'defensive ethic', as it is called by Sass (1987), fails in the end to provide a workable guide 
for action is due to an inadequate underlying philosophy of technology (the technological imperative, the inherent evil of 'reductionism') but also the fact that its arguments against controversial genetic procedures such as GLT are unfocused. Often, they seem to be really directed against ameliorative manipulations or else they could apply, in a naturalistic vein, against many other medical practices and many technologies in general, new or old. Rarely do the specifics of GLT seem to be clearly addressed. This lack of focus, together with a liberal use of the slippery-slope argument, leads to an inflationary process of advocating more and more sweeping prohibitions. Although Jonas himself seems occasionally to recoil from explicitly anti-science conclusions (Jonas 1985, p. 317), this is not always the case of his followers. ${ }^{5}$ This is where some degree of 'optimism' has to step in, with its guarded confidence in the ability of human society to make responsible choices, if bioethics is not to retreat into a posture of sullen impotence. ${ }^{6}$

\section{NOTES}

1 The listed papers might strike the reader as a motley collection far exceeding the limits of 'scholarly opinion'. This is because the bioethical debate in Europe is rather different from the prevailing situation in North America. Firstly, bioethics has been recognized as a distinct scholarly endeavour, separate from medical deontology, only very recently. Furthermore, Europe has discovered bioethics mainly through the problems raised by reproductive medicine (rather than genetics or human experimentation). That was the topic that led to the creation of the Warnock (UK), Benda (Germany) and Amstad (Switzerland) committees and dominated the initial work of the French Comité Consultatif National d'Ethique. Finally, there is no clear-cut division of work between individuals contributing analytical papers aiming mostly at conceptual clarification and committees and collectives of various kinds providing normative statements. The consequence is that there is one large, lively but slightly confusing bioethical debate, to which scholars, government-appointed bodies, churches, international organizations, single-issue lobbies, learned societies, informal reflexion groups at universities and health-care facilities all contribute something.

2 We are assuming here that if and when GLT moves closer to the realm of possibility, this will happen in the context of an in vitro procedure performed on embryos or unfertilized eggs, followed by embryo transfer. The transformation of sperm with exogenous DNA that stirred the interest of the biological community in 1989 is now widely recognized as having "run into sand" (Maddox, 1989) and the possibility of vectors homing in specifically on an individual's primordial germ cells brings us a few steps further into science fiction as compared to 'embryo-based' scenarios. 
3 Of course, we are not asserting that embryo selection is itself devoid of ethical problems. In fact, we are not convinced that it is the panacea that it is sometimes touted to be, i.e., an obviously superior alternative to current prenatal-diagnostic techniques (Thévoz, 1990). But a discussion of the many ethical and health-policy issues linked with it would be beyond the scope of this paper.

4 A kindred view, emphasizing the interplay of autonomy and otherness can be found in the work of the Belgian philosopher Malherbe, although he starts from very different philosophical assumptions (Malherbe, 1987).

5 See for instance Eibach (1990), who feels that gathering extensive knowledge about the human genome is unethical.

6 This paper is part of the Ethics and Genetics Project at the Louis Jeantet Foundation for Medicine, Geneva, Switzerland.

\section{REFERENCES}

Agius, E.: 1989, 'Germ-line cells - our responsibilities for future generations', Concilium 203, 105-115.

Amstad-Report: 1988, Commission d'experts pour la génétique humaine et la médicine de la reproduction: Rapport au Département fédéral de l'intérieur et au Département fédéral de justice et police, Chancellerie fédérale, Berne.

Anderson, W.F., and Fletcher, J.C.: 1980, 'Gene therapy in human beings: When is it ethical to begin?', New England Journal of Medicine 303, 1293-1297.

Anderson, W.F.: 1985, 'Human gene therapy: Scientific and ethical considerations', Journal of Medicine and Philosophy 10, 275-291.

Anderson, W.F.: 1989, 'Human gene therapy: Why draw a line?' Journal of Medicine and Philosophy 14, 681-693.

Anderson, W.F.: 1990, 'Genetics and human malleability', Hastings Center Report 20(1), 21-24.

Anon.: 1988, 'Are germ-lines special?' Nature 331, 100.

Bayertz, K.: 1987, GenEthik: Probleme der Technisierung menschlicher Fortpflanzung, Rowohlt, Reinbek bei Hamburg.

'Benda-Report': 1986, Bericht der Arbeitsgruppe in-vitro Fertilisation, Genomanalyse und Gentherapie, J. Schweitzer Verlag, München.

Böckle, F.: 1988, 'Biotechnik und Menschenwürde', Bulletin des Médecins Suisses 69(48), 2107-2114.

Bourrit, B., Mandofia, M., Mauron, A., and Thévoz, J.M.: 1989, 'Analyse de l'argumentation éthique du rapport Amstad', Bulletin des Médecins Suisses 70(43), 1823-1828.

Council of Europe (Parlamentary Assembly): 1982, Recommendation 934 (1982) on genetic engineering, Council of Europe, Strasbourg.

Council of Europe (Parlamentary Assembly): 1989, Recommendation 1100 (1989) on the use of human embryos and fetuses in scientific research, Council of Europe, Strasbourg.

Culliton, B.: 1989, 'Designing cells to deliver drugs', Science 246, 746-751. 
Eibach, U.: 1990, 'Genomanalyse und Menschenwürde - Eine theologischethische Stellungnahme,' Ethik in der Medizin 2, 22-36.

'EMRC': 1988, 'Gene therapy in man, recommendations of European medical research councils', The Lancet 1:8597 (June 4), 1271-1272.

Engelhardt, H.T.: 1986, The Foundations of Bioethics, Oxford University Press, Oxford, New York.

Engelhardt, H.T.: 1987, 'Gentherapie an menschlichen Keimbahnzellen: Kann und soll die "Schöne neue Welt" verhindert werden?", in V. Braun (ed.), Ethische und rechtliche Fragen der Gentechnologie und der Reproduktionsmedizin, J. Schweitzer Verlag, München, pp. 255-262.

Fifth International Summit Conference on Bioethics: 1988, 'Recommendations', in Capron, A.M., 'The Rome bioethics summit', Hastings Center Report 18(4), Supplement 11-13.

Fowler, G., Juengst, E.T., and Zimmerman, B.K.: 1989, 'Germ-line gene therapy and the clinical ethos of medical genetics', Theoretical Medicine 10, 151-165.

Glover, J.: 1984, What Sort of People Should There Be?, Penguin Books, London.

Handyside, A.: 1990, 'Sex and the single cell', New Scientist 126 (April 21), 34-35.

Jonas, H.: 1979, Das Prinzip Verantwortung: Versuch einer Ethik für die technologische Zivilisation, Insel Verlag, Frankfurt.

Jonas, H.: 1985, Technik, Medizin und Ethik: Praxis des Prinzips Verantwortung, Insel Verlag, Frankfurt.

Kaplan, J.C., and Delpech, M.: 1989, Biologie moléculaire et médecine, Flammarion, Paris.

Livre Blanc des recommandations, Huber G.: 1990, Patrimoine génétique et Droits de l'Humanité, Osiris, Paris.

Maddox, J.: 1989, 'Transgenic route runs into sand', Nature 341, 686.

Malherbe, J.F.: 1987, Pour une éthique de la médecine, Larousse, Paris.

Mouvement Universel pour la Responsabilité Scientifique: 1989, 'Propositions', Cahiers du M.U.R.S. 18, 13.

'NHMRC': 1987, Ethical Aspects of Research on Human Gene Therapy, Report to the National Health and Medical Research Council by the Medical Research Ethics Committee of NHMRC, Australian Government Publishing Service, Canberra.

Office of Technology Assessment: 1984, Human Gene Therapy - Background Paper, U.S. Congress, Office of Technology Assessment, Washington DC.

Pembrey, M.: 1988, 'Germ-line quandary', Nature 332, 10.

Ruh, H.: 1989, 'Ethische Aspekte der Biologie', Bulletin des médecins suisses 70(49), 2080-2083.

Sass, H.M.: 1987, 'Methoden ethischer Güterabwägung in der Biotechnologie', in V. Braun (ed.), Ethische und rechtliche Fragen der Gentechnologie und der Reproduktionsmedizin, J. Schweitzer Verlag, München, pp. 89-110.

Sass, H.M.: 1988, 'A critique of the enquete commission's report on gene technology', Bioethics 2, 264-275.

Thévoz, J.M.: 1990, Entre nos mains l'embryon, Recherche bioéthique, Labor et Fides, Geneva. 
U.S. National Institutes of Health: 1989, 'Points to consider in the design and submission of protocols for the transfer of recombinant DNA into human subjects', Recombinant DNA Technical Bulletin 12(3), 157-170.

Vogel, F.: 1989, Humangenetik in der Welt von heute, Springer-Verlag, Berlin.

Vogel, F., and Motulsky, A.G.: 1986, Human Genetics: Problems and Approaches, 2nd Edition, Springer-Verlag, Berlin.

Walters. L.: 1986, 'The ethics of human gene therapy', Nature 320, 225-227.

Watson, J.D., and Tooze, J.: 1981, The DNA Story: A Documentary History of Gene Cloning, W.H. Freeman, San Francisco.

Weatherall, D.J.: 1988, 'The slow road to gene therapy', Nature 331, 13-14.

Williams, B.: 1985, 'Which slopes are slippery', in M. Lockwood (ed.), Moral Dilemmas in Modern Medicine, Oxford University Press, Oxford, pp. 126-137.

Wolff, P., et al.: 1990, 'Direct gene transfer into mouse muscle in vivo', Science 247, 1465-1468. 